ścijaństwa. Rrozdział III (Genovefa s’ territory) jest poświęcony życiu i środowisku Genowefy, napisany na podstawie wspomnianego Vita. Rozdział IV (Paris after Genovefa) opisuje historię duchowego patronatu Genowefy nad miastem Paryż.

Pozostałe cztery rozdziały dotyczą drugiej omawianej tu świętej - Brygidy oraz środowiska południowo-irlandzkiego, z którego pochodziła. Zatem rozdział V (Crossings and controversions) wprowadza w zagadnienie chrystianizacji Irlandii przed V wiekiem i wpływów rzymsko-brytońskich. Rozdział VI (Ekphrasis at Kildare) omawia żywot św. Brygidy na podstawie utworu spisanego przez Cogitosusa w charakterze „,architekturalnej hagiografii” (ekphrasis), łączącej legendarno-historyczny życiorys świętej z początkami architektury kościelnej w Kildare, czyli pokazuje jej twórczy impuls na tle kształtującej się powoli religii chrześcijańskiej i architektury kościelnej, której dawała początki. Rozdział VII (Brigit goes to ground) demaskuje legendę i opisuje historyczne kolejne fazy niełatwego pochodu chrześcijaństwa w Irlandii Południowej za czasów Brygidy i po jej śmierci, oraz thumaczy jej autorytatywną rolę w późniejszych wiekach. Ostatni rozdział (Relics) opisuje losy relikwii (doczesnych szczątków i pozostałości po obydwu świętych), historyczne próby wymazania ich kultu wobec zaginięcia relikwii, wreszcie rehabilitację tego kultu w obliczu współczesnych badań.

Książka prof. L. Bitel pokazuje, że mamy do czynienia z nietuzinkowym badaczem historykiem, który nie daje łatwo wiary legendom i nie poddaje się wobec skąpych wzmianek historycznych. Można być zaskoczonym rozległością i fachowością jej badań nie tylko z zakresu historii, ale również literatury, antropologii, hagiografii czy architektury. Jako owoc jej wysiłku, powstała wspaniała praca, owoc jej kilkuletnich badań, która otwiera nowe sposoby patrzenia na starą wielowiekową tradycję: ta zaś każe widzieć w tych dwóch świętych niewiastach: Genowefie i Brygidzie, wyjątkowych budowniczych cywilizacji chrześcijańskiej Francji i Irlandii u ich początków. Pozostaje życzenie, by owoce tej pracy i im podobne docierały do naszego polskiego środowiska teologiczno-naukowego i kształtowały powoli prawidłowy punkt widzenia zamierzchłej historii ukrytej w mrokach legend i ruin.

Ks. Ryszard Groń - Chicago, USA

\title{
Richard J. FOSTER - Gayle D. BEEBE, Longing for God. Seven paths of Christian Devotion, Downers Grove Il. 2009, Inter Varsity Press, ss. 349.
}

Autor Gayle Beebe szczęśliwy, że dzięki kilku ludziom (m. in. Richardowi Fosterowi) spotkał na swojej drodze życia Boga, postanowił podzielić się tym doświadczeniem, i w obliczu wielu egzystencjalno-filozoficznych pytań, które przez lata zadawali mu znajomi i przyjaciele, odpowiedzieć praktycznymi drogami duchowości chrześcijańskiej. Są to w rzeczywistości wykłady obydwu autorów: Richarda Fostera i Gayle Beebe, jakie dali po raz pierwszy na Uniwersytecie 
Południowej Karoliny w 1992 r., które z czasem przygotowali do formy obecnej książki (s. 9-10).

Autorom przyświecały dwa cele: chcieli pokazać siedem dróg dogłębnego doświadczenia Boga na przestrzeni wieków chrześcijaństwa, by w ten sposób pobudzić i pomóc innym zrozumieć potrzebę głębszej i zażyłej relacji z Bogiem oraz różne sposoby jej realizacji. Drogę wytyczali poszczególni świątobliwi mężowie i niewiasty: klasycy, czasami kilku z nich, którzy ich zakosztowali i pierwsi wyznaczyli jej szlaki. Dróg jest wiele, jak wiele jest sposobów doświadczenia Boga, choć w ostateczności wszystkie one wcześniej czy później mogą być udziałem tego samego życia (s. 11-15). One też wyznaczyły kryterium podziału całej książki na siedem rozdziałów omawiając życie duchowe, jako:

- prawidłowe uporządkowanie naszej miłości do Boga, w mniemaniu autorów, szlak reprezentowany przez: Orygenesa (w poszukiwaniu wiecznej wspólnoty z Bogiem), Augustyna z Hippony (w miłowaniu Boga całym ciałem, umysłem i sercem), Bernarda z Clairvaux (w pragnieniu Boga i osiąganiu czystej miłości) i Błażeja Pascala (w prawidłowym uporządkowaniu ciała, umysłu i serca); rozważania te wyznaczyły treść pierwszego rozdziału;

- podróż według autorów, szlak reprezentowany przez: Ewagriusza z Pontu (droga od śmiertelnych myśli do Bożych cnót), Jerzego Herberta (splatanie życia w sensowną całość), Jana Bunyana (szlak pielgrzymi do Boga), Tomasza Mertona (znalezienie naszego domu z Bogiem); rozważania te wyznaczyły treść drugiego rozdziału;

- odzyskiwanie wiedzy Boga zagubionej po upadku, szlak reprezentowany przez: Tomasza z Akwinu (nauczanie miłowania i stosunkowo pełnego poznania Boga), Marcina Lutra (wzrastanie w wolności Bożej miłości) i Jana Kalwina (znajomość Boga i samego siebie); rozważania te wyznaczyły treść trzeciego rozdziału;

- zażyłość z Jezusem Chrystusem, droga reprezentowana przez: Franciszka z Asyżu (świat jako nasz klasztor), św. Bonawentury (pełnia życia w Chrystusie), Tomasza a Kempis (imitacja Chrystusa) i Ignacego z Loyoli (prowdzenie przez tajemnice Chrystusa); rozważania te wyznaczyły treść czwartego rozdziału;

- prawidłowe uporządkowanie naszych doświadczeń Boga, ścieżka ukształtowana przez: Juliannę Norwich (objęci dobrocią Boga), Jerzego Foxa (nauka kroczenia w świetle Chrystusa), Jana Wesleya (rola naszego doświadczenia religijnego w poznaniu Boga) i Fryderyka Schleiermachera (usensowić nasze doświadczenie Boga); rozważania te wyznaczyły treść piątego rozdziału;

- akcja i kontemplacja, droga utorowana przez Jana Kasjana (zachowanie równowagi życia aktywnego i kontemplacji), Benedykta z Nursji (nauka życia poprzez Regutę) i Grzegorza Wielkiego (kontemplacyjny sposób aktywnego życia); rozważania te wyznaczyły treść szóstego rozdziału;

- Boży wzrost, szlak utorowany przez: Pseudo Dionizego (miłowanie Boga w potrójny sposób), autora Obłoku niewiedzy (ostre strzały tęskniącej miłości), Teresę z Avila (wejść do mieszkania Chrystusa), Jana od Krzyża (oświecić ciemną 
noc wiary); rozważania te wyznaczyły treść ostatniego rozdziału prezentowanej książki.

Książkę kończą wnioski, trzy apendyksy, podziękowanie oraz spis treści. Autorzy raz jeszcze podkreślają, że wszystkie wymienione ścieżki duchowe prowadzące do Boga nie są wyłączne i można je doświadczyć w swoim życiu w zależności od sytuacji i warunków. W rzeczywistości nie jest ważne, którą z nich obierzemy, ważne jest, by podążać w naszym puszukiwaniu Boga korzystając z bogatego doświadczenia poprzednich pokoleń. Książka, oprócz bogactwa wiedzy na temat duchowości chrześcijańskiej, wydaje się być praktycznym przewodnikiem po duchowych scieżkach podając współczesnemu, nieraz zagubionemu i sfrustrowanemu człowiekowi, konkretne formy zbliżania się do Boga. Pomagają w tym specjalne paragrafy kończące każdą omawianą ścieżkę, a nawet każdą omawianą osobę, pt. Reflecting i responding (Rozważając i odpowiadając). W ten sposób można znaleźć konkretne wskazówki i formy pójścia daną drogą we współczesnej rzeczywistości.

Dodatkowym atutem książki są apendyksy zawierające: (1) przedchrześcijańskie wpływy na naszą duchowość (stoicyzm, platonizm, arystotelizm, hebrajskie myślenie biblijne i teologia żydowska, Jezus i jego uczniowie); (2) przykłady pozostałych świętych mężczyzn i niewiast, nie ujętych w poszczególnych drogach, których jednak doświadczenie Boga, mimo braku specjalnej edukacji, jest godne zauważenia i naśladowania; (3) wreszcie wkład wschodniego prawosławnego Kościoła do naszej duchowości. Warto mieć pod bokiem ten swoisty rodzaj podręcznika duchowości katolickiej, by móc pomóc sobie i innym w poszukiwaniu Boga.

Ks. Ryszard Groń - Chicago, USA

\section{Medieval Christianity in Practice, ed. Miri RUBIN, Princeton - Oxford 2009, Princeton University Press, ss. 346.}

To już kolejna recenzowana przez nas, tym razem zbiorowa publikacja pod redakcją Miri Rubin, profesor historii średniowiecza w Queen Mary University w Londynie. Profesor Rubin podejmuje w niej postulat wydawnictwa Princeton University Press, które w ramach serii „Princeton Reading in Religions” próbuje ukazać różne religie i ich przełomowe okresy historyczne w praktycznej formie. Dotychczas w ramach tej serii ukazały się: religie Indii, buddyzm, religie Chin, Tybetu, Japonii, Tantry, Azji, religie późnego antyku, judaizm, religie USA, historyczny Jezus w kontekście, islam w południowej Azji, a w przygotowaniu są Zen i Yoga w praktyce. Wydaje się na tym tle, że w przypadku omawianej pozycji okres średniowieczny został potraktowany wyjątkowo, jako moment przełomowy chrześcijaństwa, decydujący o jego współczesnym kształcie i strukturze.

Niniejsza książka, na wzór poprzednich tomów z serii „Religia w praktyce”, bierze pod uwagę teksty źródłowe poszczególnych wydarzeń z praktyki życia re- 